\title{
Determination of Some Growth Characteristics and Some Blood Values of The Goat Kids Fed with the Feed Containing Whey and Propolis
}

\section{Selda MANAV}

Adnan Menderes Üniversitesi: Adnan Menderes Universitesi

Murat YILMAZ ( $\sim$ myilmaz@adu.edu.tr)

Adnan Menderes University Agriculture Faculty

\section{Research Article}

Keywords: Goat Kids, Whey, Propolis, Growth Characteristics, Blood Values, Diarrhea

Posted Date: July 8th, 2021

DOI: https://doi.org/10.21203/rs.3.rs-647797/v1

License: (c) (i) This work is licensed under a Creative Commons Attribution 4.0 International License.

Read Full License 


\section{Determination of Some Growth Characteristics and Some Blood Values of The Goat Kids Fed with the Feed Containing Whey and Propolis}

Selda MANAV ${ }^{1}$, Murat YILMAZ ${ }^{1}$

${ }^{1}$ Department of Animal Science, Faculty of Agriculture, Aydin Adnan Menderes University, Aydin, Turkey

e-mail: seldaavci@adu.edu.tr - myilmaz@adu.edu.tr

\section{Abstract}

In this study, it was aimed to obtain an alternative, more economical and preferable milk substitute feed by adding whey powder to cow's milk in kid rearing and to determine the effect of propolis supplement on this diet. 40 Saanen goat kids born in the same period were divided into 4 groups, on average 7 days after taking colostrum, and while the 10 kids in the control group were kept together with their mothers. the kids in the other three groups, 10 heads in each one, were taken into seperate sections. Kids in all three experimental groups were fed only formula. In addition to the feed, $0.4 \mathrm{cc}$ and $0.2 \mathrm{cc}$ propolis were given to the kids in the second and third experimental groups, respectively, once a day. Some growth and development parameters and rectal temperature were measured once a week for 5 weeks from all groups and morning and evening diarrhea scoring was done. Some biochemical and hematological analyzes were performed. According to all the results obtained, the differences between the groups were found to be significant in terms of body temperature, glucose and urea evaluations, and the differences within the group in other characteristics were statistically significant $(\mathrm{P}<0.05)$. The insignificant difference between the average growth and development parameters of the kids in the groups fed with the formula and the average of the kids in the control group is an important result in terms of growing kids economically and bringing goat's milk to the economy. According to the diarrhea scores, it has been observed that propolis is effective on diarrhea and can be used in growing kids as a preventive measure. Feeding kids with the formula was found more economical than feeding their mother's milk. As a result of this study, it can be said that the use of milk replacers containing whey and propolis will positively affect the growth, development and health of the kid.

Key Words: Goat Kids, Whey, Propolis, Growth Characteristics, Blood Values, Diarrhea

\section{Introduction}

Goat kids losses are one of the major problems of the breeding period. After birth, the process of formation of active immune elements begins. Depending on the environmental conditions in this process and the adaptation ability of the animal, it is observed that the offspring with low resistance die in the first month (Aytug et al. 1991; Karsl1 and Evci 2018). In the studies conducted, while the kids mortality rates vary between $2.2-14 \%$ in the first 5 days after birth, this rate increases even more on the 10th day and after (Holmøy and Waage 2015; Ünal et al. 2018). In the past, the application of antibiotics to the feeds in order to prevent the loss of the offspring was prohibited due to the increase of pathogen resistance. Especially in ruminants, the search for using 
alternative feed additives instead of antibiotics has increased in rearing breeding with or without mother, against the negative effects of intestinal pathogens. For this purpose, probiotics, prebiotics, organic acids and essential oils are used commercially today (Ünlü et al. 2013; Zeng et al. 2015). Artificial growing methods are used in in sheep and goats farms for milk production, depending on the increase in the amount of marketable milk. Due to the high prices of goat milk, various food formulations have been tried in artificial enlargement applications. Whey is used as a milk substitute feed for lamb and calf feeding because of its low cost and easy supply. Gailna et al (1995) fed different genotype goat kids with cow's milk and different proportions (20-35-50\%) of PAS, and found that the live weights were statistically similar to those of animals that suck goat milk.

Propolis is an effective bee product in the formation of an aseptic environment in the hive, due to its antimicrobial activity. Propolis is collected by bees from various parts of plants and used for different purposes in the hive (Bonamigo et al. 2017; Kocot et al. 2018). It is known that Propolis is effective on various bacteria (Velikova et al. 2000; Katırcioğlu and Mercan, 2006), viruses (Kujumgiev et al. 1999; Harish et al. 1997), fungi (Murad et al., 2002) and molds (Silici et al., 2005; Kujumgiev et al. 1999).In addition, it has been determined that propolis has an immunomodulatory effect on mammals (Freitas et al. 2011; Onur et al. 2018). There are many studies on its effects on poultry (Broudiscou et al. 2002; Denli et al. 2005; Seven et al. 2007; Tekeli et al. 2011; Hašèík et al. 2012; Aygun and Sert 2013) . In ruminants, many studies have been conducted to determine the effects of propolis on rumen digestive metabolism and reproduction (Kupczyński et al. 2012; Zeedan and Komonna, 2013;Kara et al. 2014). Propolis supplementation created significant differences in some hematological values in Hanwoo calves (Yang et al. 2010). Zeedan and Komonna (2013) found that propolis supplementation to buffalo cows positively affected feed utilization, reproductive performance and milk yield, offspring birth weight and offspring immunity. In addition, it has been determined that the addition of propolis extract to calves as an anti-diarrhea reduced diarrhea symptoms in calves and increases live weight (Chudoba et al (2003) Propolis supplementation improved efficiency, oxidative status and immune response in barki sheep and lambs (Shedeed et al. 2019) However, it was determined that propolis supplementation increased body weight in Ivesi sheep (Al-Khafaj1 2016).Knowing the physiological reference values of blood in Capricorns is important in terms of providing useful information for recognizing the animal's adaptation mechanisms against the environment during the first month of their lives and for diagnosing the diseases to be experienced (Zumbo et al. 2011).In sheep and goat breeding, the emergence of self-immunity of new born kids and lambs and their adaptation to the environment is a period of economic losses due to severe kid and lamb losses. In this period, knowing certain hematological reference intervals of lambs and goats helps to evaluate their care practices, nutrition and health status in a realistic way (Abdolvahabi et al. 2018). It is also known that age has a serious effect on hematological values and hematological values change according to age (Abdolvahabi et al. 2018).Although there are studies on hematological values in most of the farm animals, there are not enough studies on goat-kids hematology, and there are very few studies on age-related hematological changes in Saanen goats on the basis of race (Zumbo et al. 2011; Abdolvahabi et al. 2018).

The aim of this study was to obtain an alternative, more economical and preferable milk substitute feed by adding PAST to cow's milk, and to determine the effect of propolis supplementation on some growth development parameters and blood values of goats. 
This study was carried out in the Goat Breeding Unit of Aydin Adnan Menderes University Faculty of Agriculture Animal Research and Application Center. The coordinates of the enterprise are $37^{\circ} 45^{\prime} 03.31^{\prime}$ ' ' N and $27^{\circ} 45^{\prime} 27.16^{\prime \prime}$ E, $52 \mathrm{~m}$ above sea level. Mediterranean climate prevails in the region. Environmental temperature and humidity measurement was determined by a Hobo device, daily ambient temperature $\left({ }^{\circ} \mathrm{C}\right)$, and relative humidity ( $\mathrm{RH}, \%)$. The mean temperature-humidity index (THI) was calculated according to equation: $\left\{(0.31-0.31 \mathrm{RH} / 100)\left(\mathrm{db}{ }^{\circ} \mathrm{C}-14.4\right)\right\}$ (Marai vd. 2007).

The animal material of the study consisted of 40 kids born at the same time from synchronized goats. 40 Goats kids were divided into four groups: Control $(n=10)$ kept free with their mothers and the group were that freely sucks their mothers, and first group: group $(\mathrm{n}=10)$ were fed only with the formula $(75 \%$ cow's milk $+10 \%$ whey $+15 \%$ water), second group were given the formula and $0.4 \mathrm{cc}$ propolis, third group were given the formula and $0.2 \mathrm{cc}$ propolis.

The kids in the control group stayed together with their mothers in a semi-open shelter of about 30 square meters and sucked their mothers freely. The mothers of the kids in the control group were not milked during the trial. The kids in the 1st, 2nd and 3rd groups were separated from their mothers and placed in $1.5 \times 1.5 \mathrm{~m}$ semi-open individual chambers and feed individually by means of a bottle twice a day with a body-temperature milk substitute made by mixing $75 \%$ cow's milk $+10 \%$ whey $+15 \%$ water. Lactopro brand whey (oil $<1.5 \%$, lactose> $5 \%$, protein $7-10 \%$, lactic acid $<15 \%$, Ph $6-6.2 \%$, salt $<2.20 \%$, Ash $<5 \%$, solubility $98 \%$, moisture $<2 \%$ ) used. The amount of the formula was given to equal $10 \%$ of the live weight of the kid, and it was increased in parallel with the live weight increase. In addition, 0.4 and $0.2 \mathrm{cc}$ ethanolic propolis extract was administered orally once a day via an injector to the 2 nd and 3 rd groups, respectively. Propolis extracts were obtained from the company named İdapolis within Çanakkale 18 Mart University Technopark. The foods consumed daily were noted for each kid. As of the third week of the experiment, $100 \mathrm{~g}$ of good quality dried clover was placed in front of each animal. As of the 4 th week, $100 \mathrm{~g}$ starter feed containing $20 \%$ crude protein and $2700 \mathrm{kcal} / \mathrm{kg}$ metabolic energy was placed in front of each animal. In order to determine the feed consumption of kids, the remaining feeds were weighed and recorded weekly. The amount of feed was increased in a controlled manner due to the increase in live weight. In the study, clean water was kept in front of the kids starting from their second week.

The kids were weighed individually every week from birth and their live weight(LW) were determined. The kids were fasted before weighing. Body condition score (BCS) was obtained after weighing. (Russell et al. 1969). Body length(BL), height of withers(HW), chest circumference $(\mathrm{CC})$ measuring were captured by stick and tape measure on a flat concrete floor. The rectal body temperature of the kids was measured every week with a digital thermometer. The daily health conditions of the animals were observed every day. Stools were checked twice a day, in the morning and evening, and stool scoring was performed using the stool consistency scaling system. The scoring ranges between 1 and 4 ( $1=$ watery; $2=$ fluid; $3=$ soft; $4=$ normal) (Ayışığ et al. 2005).

\section{Blood sampling and hematological analysis}

Blood samples were taken from animals in all groups three times in total, on the first day when the capricorns 
were grouped, in the middle of the experiment and at the end of the experiment. Blood was taken from the jugular veins of the neck (vena jugularis), approximately $10 \mathrm{ml}$, into EDTA tubes (ethylenediamine tetra acetic acid) for hematological analysis, and heparin tubes for biochemical analysis. Hemogram values were analyzed using Horiba Medical ABX Micros ABX brand device.

\section{Statistical Analysis}

Statistical analysis of the features specified in the study was performed using the linear mixed model equation defined below: $y_{i j k l}=\mu+\alpha_{i}+\tau_{j}+(\alpha \tau)_{i j}+\delta_{k}+e_{i j k l}$

$y_{i j k l}:$ i. in the group, j. day and the observation value of the $\mathrm{k}$. individual of gender 1 . in terms of the analyzed feature, $\mu$;Overall mean, $\alpha_{i}: 1$. the effect of the group (i: Group-1, Group-2, Group3 and Control), $\tau_{j}:$ j. effect of the day $(\mathrm{j}: 1,8,14,21,30,37),(\alpha \tau)_{i j}$ : group and day interaction, $\delta_{k}: k$. influence of gender (k: Male and Female) ve $e_{i j k l}$ : Random error term. The mixed model equation described above was applied to the analysis of the data using the nlme (Linear and Nonlinear Mixed Effects Models) package (Pinheiro et al. 2013) defined in the R-packet (R Core Team) program with $\Omega$ variance-covariance error matrix. Unstructured variancecovariance structure was determined using Schwarz's Bayesian Criterion (Littell et al. 1997). After the variance and covariances in the $\Omega_{-}$i matrix were estimated by the maximum likelihood method, whether the factors in the linear mixed model equation were statistically significant was determined by the F-test. The significance of the differences between the levels of statistically significant factors was determined by applying the Tukey test at the $\mathrm{p}<0.05$ significance level.

\section{RESULTS}

\section{Climatic and Geographical Conditions}

The place where the experiment was conducted is $52 \mathrm{~m}$ above sea level and in a region with a Mediterranean climate and the temperature difference between day and night is high. During the trial, the lowest temperature is $1{ }^{\circ} \mathrm{C}$ and the highest temperature is $27^{\circ} \mathrm{C}$. The average humidity varied between 57 and $68 \%$. Temperature humidity index was found to be between 10.58 and 16.72 .

\section{Live Weights, BCS and Body Measurements}

Table 1. There was no difference between the groups in terms of live weight (LW) during the trial period. In each group, the differences within the group were found to be statistically significant $(\mathrm{P}<0.05)$. The fact that there was no statistical difference between the control group and the other 3 groups in terms of body weight gain was important in terms of showing that animals could gain similar body weight with milk substitute feed.

According to the bcs measurements made every week, it was seen that there was no statistical difference between the groups in terms of BCS averages in the first, second, fifth and sixth measurements. In the third and fourth measurements, the difference between group 3 and control group was found to be statistically significant ( $\mathrm{P}<0.05)$. When we evaluated the groups within themselves, the difference between the means was found to be insignificant in all groups except the control group. it could be said that the control group had a higher rate of fat 
than the other groups.

Table 1. Least squares means and standard errors of the kids' Live Weights, BCS and Body Measurements

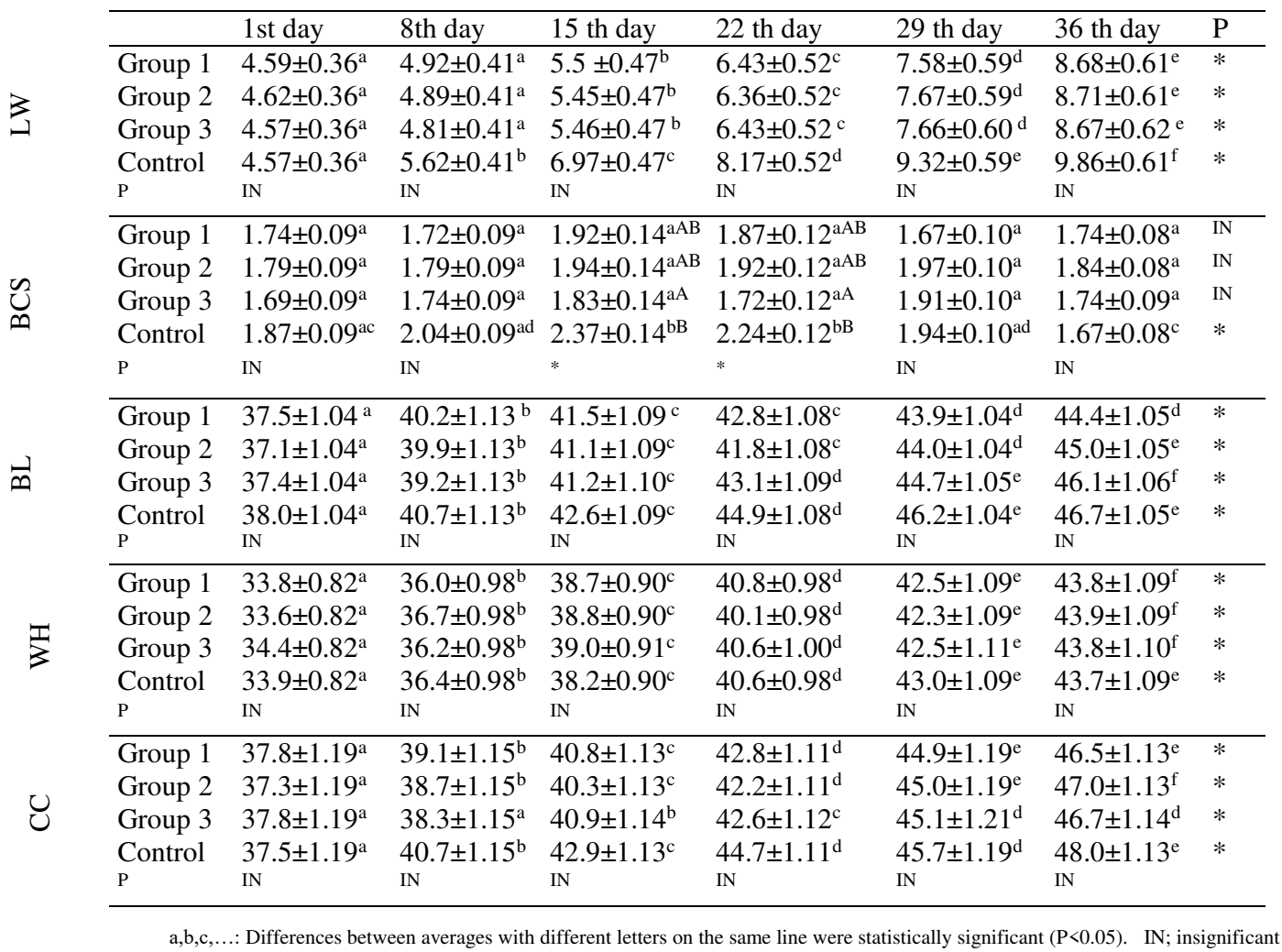

There was no difference between the groups in terms of body length averages during the trial period. When the comparison was made within the groups, Within the groups, the differences were found statistically significant in terms of body length averages in each group during the trial period and in group 3, statistical significance was determined among all measurement averages $(\mathrm{P}<0.05)$. In group 1, the means of the first, second, third, fourth and sixth measurements were different from each other, and the mean of the fifth and fourth and sixth measurements were statistically similar $(\mathrm{P}<0.05)$. In the first 3 measurements in all groups, it was determined that the body lengths were statistically different from each other. Only in group 3, statistical significance was determined among all measurement averages $(\mathrm{P}<0.05)$. Compared to the control group, the first $\mathrm{BL}$ measurements were lower, the second and third groups, who were given different doses of propolis in addition to the formula, had a body length of $46 \mathrm{~cm}(45 \mathrm{~cm}, 46 \mathrm{~cm})$ reached by the control group at the last measurement, and it was longer compared to the first group given only formula (Table 1). The differences between the first measurement average BL values and the last measurement average BL values of kids in the 1st, 2nd, 3rd and control groups were respectively $6.9,7.9,8.7$ and $8.7 \mathrm{~cm}$. There was no difference between the third group and the control group and it was observed that their body length increased at the same rate. In addition, between the 5th and 6th measurements, it was seen that the animals in the control group changed very little in terms of body length and remained almost constant. However, it is seen that the increases continued at higher levels in the 2nd and 3rd groups who were given formula and propolis in different doses. 
When the comparison between the groups was made, there was no statistically significant difference in terms of WH during the trial period. When the comparison in each the group, the difference between the measurement averages in all weeks was statistically significant $(\mathrm{P}<0.05)$. All measurements of the control group except the last two measurements were found to be statistically different from each other $(\mathrm{P}<0.05)$. It was observed that the average wither heights of the kids in the control group were the same in the last two measurements (Table 1) In terms of first measurement values, it is seen that group 2 with the lowest WH. $(33.6 \mathrm{~cm})$ has the highest value $(43.9 \mathrm{~cm})$ in the last measurements. At the end of the experiment, it was observed that all three experimental groups fed with the formula had almost equal wither height with the control group that continuously sucked their mother (Table 1).

176

Table 2. Least squares means and standard errors of the kids' BT $\left({ }^{\circ} \mathrm{C}\right)$ $2(\mathrm{P}<0.05)$. $46.7 \mathrm{~cm}$ in the third row and 1 group with $46.5 \mathrm{~cm}$ in the last row (Table 1). statistically significant $(\mathrm{P}<0.05)$.

In the comparison between the groups, there was no statistically significant difference in terms of CC during the trial $(\mathrm{P}<0.05)$. Considering the comparison in the groups, in the 1st, 2nd, 3rd and countrol groups, the difference between the measurement averages in all weeks was statistically significant $(\mathrm{P}<0.05)$, it was determined that the $\mathrm{CC}$ was statistically different from each other in the measurements in all weeks only in group

In Group 1, the difference between the mean chest circumference in the first five measurements was found to be statistically significant, but the difference between the averages at the 5th and 6th weeks was found to be insignificant $(\mathrm{P}<0.05)$. In the control group, the differences between the 1st, 2nd, 3rd, 4th and 6th week measurements were found to be statistically significant, the differences between the measurements at the 4th and 5th weeks were found to be insignificant $(\mathrm{P}<0.05)$. In Group 3, the difference between the $3 \mathrm{rd}$ and 4 th measurements and the differences between these measurements and the other measurements were found significant $(\mathrm{P}<0.05)$. At the end of the trial, the highest chest circumference measurement with $48 \mathrm{~cm}$ was in the control group. While there was the second group with $47 \mathrm{~cm}$ in the second row, there was the third group with

Between the groups, the differences between the measurement values in the first, second, fourth and fifth weeks in terms of mean body temperature were statistically insignificant; The difference between the third and sixth measurement values was statistically significant $(\mathrm{p}<0.05)$. When the comparison between in groups was made, the difference between the average body temperatures measured in all weeks in the control group was statistically insignificant. The difference within weeks in the experiment groups (1., 2., 3.) was found to be

\begin{tabular}{cccccccc}
\hline & 1st day & 8th day & 15 th day & 22 th day & 29 th day & 36 th day & P \\
\hline Group 1 & $39.53 \pm 0.09^{\mathrm{ab}}$ & $39.47 \pm 0.09^{\mathrm{ab}}$ & $39.54 \pm 0.06^{\mathrm{aA}}$ & $39.64 \pm 0.08^{\mathrm{a}}$ & $39.47 \pm 0.10^{\mathrm{ab}}$ & $39.24 \pm 0.06^{\mathrm{bA}}$ & $*$ \\
Group 2 & $39.78 \pm 0.09^{\mathrm{a}}$ & $39.29 \pm 0.09^{\mathrm{bc}}$ & $39.23 \pm 0.06^{\mathrm{bB}}$ & $39.77 \pm 0.08^{\mathrm{a}}$ & $39.46 \pm 0.10^{\mathrm{abc}}$ & $39.45 \pm 0.06^{\mathrm{cAB}}$ & $*$ \\
Group 3 & $39.75 \pm 0.09^{\mathrm{a}}$ & $39.41 \pm 0.09^{\mathrm{b}}$ & $39.29 \pm 0,07^{\mathrm{abB}}$ & $39.62 \pm 0.09^{\mathrm{ab}}$ & $39.41 \pm 0.10^{\mathrm{ab}}$ & $39.30 \pm 0.06^{\mathrm{bA}}$ & $*$ \\
Control & $39.77 \pm 0.09^{\mathrm{a}}$ & $39.48 \pm 0.09^{\mathrm{a}}$ & $39.47 \pm 0.06^{\mathrm{aAB}}$ & $39.61 \pm 0.08^{\mathrm{a}}$ & $39.54 \pm 0.10^{\mathrm{a}}$ & $39.53 \pm 0.06^{\mathrm{aB}}$ & $\mathrm{IN}$ \\
$\mathrm{P}$ & $\mathrm{IN}$ & $\mathrm{IN}$ & ${ }^{*}$ & $\mathrm{IN}$ & $\mathrm{IN}$ & $*$ & \\
\hline a,b,c,... Differences between averages with different letters on the same line were statistically significant $(\mathrm{P}<0.05)$. & IN; insignificant &
\end{tabular}


In the blood samples taken at the beginning and at the end of the experiment, it was observed that there was no statistical difference between the groups in terms of glucose levels $(\mathrm{p}<0.05)$. However, in the second analysis mean, the difference between the groups was found to be statistically significant $(\mathrm{P}<0.05)$. In the evaluation between groups, the difference between group 2 and group 3 was statistically insignificant in the second analysis, while the difference between group 3 and control and group 1 was found to be statistically significant(Table2). In the in-group evaluation, there is no significant difference in the control group, group 1 and group 2. In group third, the differences between the first and last analyzes were not found to be statistically significant; however, a significant difference was found between the baseline and final analysis and the middle analysis $(\mathrm{P}<0.05)$.

Table 3. Least squares means and standard errors of the kids' Urea(mg/Dl)

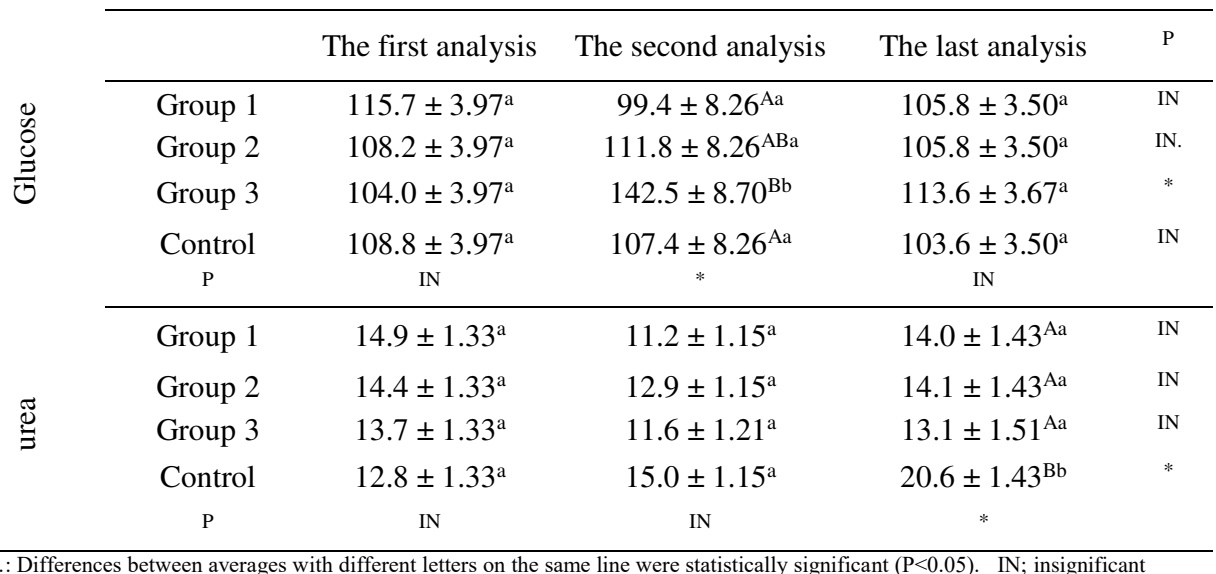

$\mathrm{a}, \mathrm{b}, \mathrm{c}, \ldots .$. : Differences between averages with different letters on the same line were statistically significant $(\mathrm{P}<0.05) . \quad$ IN; insignificant

A,B,.. :Differences between means with different letters in the same column were statistically significant. $(\mathrm{P}<0.05)$.

It was observed that there was no statistical difference between the groups in terms of mean blood urea amount obtained in the first and second blood analyzes ( $\mathrm{p}<0.05)$. However, the difference between the groups in the mean blood urea amount obtained from the last analysis was found to be insignificant for groups 1, 2 and 3 , and significant for the control group $(\mathrm{P}<0.05)$. In the evaluation within the group, the difference between the three periods analysis in the control group was found to be statistically significant $(\mathrm{P}<0.05)$.

Table 4. Least squares means and standard errors of the kids' some hematological values

\begin{tabular}{|c|c|c|c|c|}
\hline & The first analysis & The second analysis & The last analysis & $\mathrm{P}$ \\
\hline Group 1 & $6.31 \pm 0.332^{\mathrm{a}}$ & $7.26 \pm 0.266^{\mathrm{b}}$ & $8.64 \pm 0.266^{c}$ & $*$ \\
\hline Group 2 & $6.79 \pm 0.340^{\mathrm{a}}$ & $7.70 \pm 0.262^{b}$ & $8.63 \pm 0.262^{b}$ & $*$ \\
\hline Group 3 & $6.33 \pm 0.340^{\mathrm{a}}$ & $6.67 \pm 0.275^{\mathrm{a}}$ & $8.64 \pm 0.275^{b}$ & $*$ \\
\hline \multirow[t]{2}{*}{ Control } & $6.98 \pm 0.332^{\mathrm{a}}$ & $7.36 \pm 0.266^{\mathrm{a}}$ & $8.83 \pm 0.266^{b}$ & $*$ \\
\hline & IN & IN & IN & \multirow[b]{2}{*}{ IN } \\
\hline Group 1 & $7.61 \pm 0.362^{\mathrm{a}}$ & $8.17 \pm 0.235^{\mathrm{a}}$ & $8.44 \pm 0.297^{a}$ & \\
\hline Group 2 & $8.17 \pm 0.372^{\mathrm{a}}$ & $8.15 \pm 0.234^{\mathrm{a}}$ & $8.36 \pm 0.295^{\mathrm{a}}$ & IN \\
\hline Group 3 & $7.78 \pm 0.373^{\mathrm{a}}$ & $7.77 \pm 0.240^{\mathrm{a}}$ & $8.33 \pm 0.309^{\mathrm{a}}$ & IN. \\
\hline \multirow[t]{2}{*}{ Control } & $8.26 \pm 0.362^{a}$ & $7.54 \pm 0.235^{b}$ & $8.23 \pm 0.297^{\mathrm{ab}}$ & $*$ \\
\hline & IN & IN & IN & \\
\hline
\end{tabular}




\begin{tabular}{|c|c|c|c|}
\hline Group 1 & $23.1 \pm 1.390^{\mathrm{a}}$ & $24.1 \pm 0.924^{\mathrm{a}}$ & $24.7 \pm 0.919^{\mathrm{a}}$ \\
\hline Group 2 & $25.5 \pm 1.409^{\mathrm{a}}$ & $24.0 \pm 0.903^{\mathrm{a}}$ & $25.1 \pm 0.898^{a}$ \\
\hline Group 3 & $24.0 \pm 1.410^{\mathrm{a}}$ & $23.2 \pm 0.927^{\mathrm{a}}$ & $25.1 \pm 0.942^{\mathrm{a}}$ \\
\hline Control & $\begin{array}{c}26.2 \pm 1.390^{\mathrm{a}} \\
\mathrm{IN}\end{array}$ & $\begin{array}{r}23.1 \pm 0.924^{\mathrm{b}} \\
\mathrm{IN}\end{array}$ & $24.6 \pm 0.919^{\mathrm{ab}}$ \\
\hline Group 1 & $13.4 \pm 0.436^{\mathrm{ab}}$ & $12.6 \pm 0.685^{\mathrm{a}}$ & $14.3 \pm 0.755^{b}$ \\
\hline Group 2 & $13.8 \pm 0.446^{\mathrm{a}}$ & $13.4 \pm 0.683^{\mathrm{a}}$ & $13.5 \pm 0.753^{\mathrm{a}}$ \\
\hline Group 3 & $13.8 \pm 0.446^{\mathrm{ab}}$ & $12.9 \pm 0.703^{\mathrm{a}}$ & $15.2 \pm 0.789^{b}$ \\
\hline Control & $\begin{array}{c}13.3 \pm 0.436^{\mathrm{a}} \\
\text { IN }\end{array}$ & $\begin{array}{c}11.6 \pm 0.685^{\mathrm{b}} \\
\text { IN }\end{array}$ & $\underset{\text { IN }}{13.9 \pm 0.755^{\mathrm{a}}}$ \\
\hline Group 1 & $50.3 \pm 2.83^{\mathrm{a}}$ & $49.2 \pm 2.45^{\mathrm{a}}$ & $43.0 \pm 3.18^{\mathrm{a}}$ \\
\hline Group 2 & $54.4 \pm 2.93^{\mathrm{a}}$ & $47.2 \pm 2.44^{b}$ & $44.9 \pm 3.16^{\mathrm{b}}$ \\
\hline Group 3 & $49.7 \pm 2.93^{\mathrm{a}}$ & $46.2 \pm 2.52^{\mathrm{a}}$ & $42.7 \pm 3.32^{\mathrm{a}}$ \\
\hline Control & $\underset{\text { IN }}{53.5 \pm 2.83^{\mathrm{a}}}$ & $\begin{array}{r}46.9 \pm 2.45^{\mathrm{b}} \\
\mathrm{IN}\end{array}$ & $\underset{\text { IN }}{38.2 \pm 3.18^{c}}$ \\
\hline Group 1 & $3.79 \pm 1.119^{\mathrm{a}}$ & $3.85 \pm 0.463^{\mathrm{a}}$ & $6.00 \pm 0.948^{\mathrm{a}}$ \\
\hline Group 2 & $4.22 \pm 1.174^{\mathrm{a}}$ & $4.73 \pm 0.462^{\mathrm{a}}$ & $4.79 \pm 0.948^{\mathrm{a}}$ \\
\hline Group 3 & $5.41 \pm 1.174^{\mathrm{a}}$ & $3.43 \pm 0.485^{\mathrm{a}}$ & $5.94 \pm 0.996^{\mathrm{a}}$ \\
\hline Control & $3.60 \pm \underbrace{1.119^{\mathrm{a}}}_{\text {IN }}$ & $\begin{array}{c}3.65 \pm 0.463^{\mathrm{a}} \\
\text { IN }\end{array}$ & $\begin{array}{c}8.32 \pm 0.948^{b} \\
\text { IN }\end{array}$ \\
\hline Group 1 & $45.8 \pm 2.65^{\mathrm{a}}$ & $46.9 \pm 2.46^{\mathrm{a}}$ & $51.0 \pm 2.53^{\mathrm{a}}$ \\
\hline Group 2 & $41.6 \pm 2.74^{\mathrm{a}}$ & $46.1 \pm 2.44^{\mathrm{ab}}$ & $50.1 \pm 2.51^{b}$ \\
\hline Group 3 & $44.7 \pm 2.74^{\mathrm{a}}$ & $51.7 \pm 2.53^{b}$ & $50.3 \pm 2.63^{\mathrm{ab}}$ \\
\hline Control & $41.8 \pm 2.65^{\mathrm{a}}$ & $49.6 \pm 2.46^{\mathrm{b}}$ & $53.4 \pm 2.53^{b}$ \\
\hline & IN & IN & IN \\
\hline
\end{tabular}

219 When each group was evaluated within itself, RBC analyzes were found important in all groups. however, for

220 the 1st group, the difference between the RBC averages in blood samples taken in all three analyzes was found

221 to be significant. The difference between the 1st and 2nd analyzes for the control and 3rd groups was not

222 significant, the difference between the 1st, 2nd and 3rd analysis averages was found to be significant (p <0.05).

223 Since the first analysis, there was a continuous increase in RBC averages in all groups (Table 4).

224 The difference between the blood HGB ( $\mathrm{g} / \mathrm{dL})$ rates between the groups was found to be statistically 225 insignificant. In the within-group evaluation, the relationship between the three analysis values of the 1 st, $2 \mathrm{nd}$ and 3rd groups was found to be insignificant. Only the difference between the mean HGB values in the first and second analysis in the control group was found to be significant $(\mathrm{p}<0.05)$. Also, there was a decrease in the second analysis of the control group compared to the first analysis. In other groups, this decrease is at a lower level (Table 4).

In this study, there was no statistically significant difference between the groups in terms of blood HCT rates. In the within-group evaluation, the difference between the mean HCT between the first analysis and the second analysis in the control group was found to be statistically significant ( $\mathrm{p}<0.05)$. There was a steady increase in the HTC value only in group 1. In the other groups, first a decrease and then an increase was observed (Table 4).

234 There was no significant difference between the groups in terms of MCH values. In the within-group evaluation, 235 the differences between the analyzes were found to be significant in all groups except for the second group ( $\mathrm{p}$ 
$<0.05$ ). While the values were quite stable in group 2 , it was observed that there was an increase in the control group, 3rd group and 1st group after the second analysis.

In terms of LYM\%, the difference between groups was found to be insignificant. In the within-group evaluation, the differences between the analyzes in the second group and control groups in all three periods were found to be statistically significant $(\mathrm{p}<0.05)$. While the difference between the first analysis and the second and third analysis was significant in the second group, the difference between the values in all three analyzes was significant in the control group ( $\mathrm{p}<0.05$ ). In the second analysis, it was seen that the LYM\% values in kids aged 22 days were close to the control group. In addition, it was found that there was a greater decrease between the first and the second analysis in the control and the second group compared to the other groups. For the 1st, 2nd, 3rd groups and the control group, the difference between the first analysis and the last analysis of LYM\%, was found as 7.3, 9.5, 7, 15.3, respectively. The biggest decrease was seen in the control group (Table 4).

The difference between the groups in terms of monocyte ratios was statistically insignificant. In the within-group evaluation, the difference in monocyte ratios among all analyzes for the 1st, 2nd and 3rd groups was found to be insignificant. However, the difference in monocyte ratios between the first and second analysis and the third analysis in the control group was found to be significant $(\mathrm{p}<0.05)$. A rapid rise was observed in the last analysis of the control group (Table 4).

The difference between groups was not found to be statistically significant for Granulocyte \%(GRA) (Table 4). In the within-group evaluation, the difference between the mean values in all groups except the 1st group was found to be statistically significant $(\mathrm{p}<0.05)$. The differences between the first and the last analysis were significant in the second group, while the differences between the first and the second analysis in the third group were significant $(\mathrm{p}<0.05)$. In the control group, the mean of the second and last analyzes were similar, the difference between the second and last analysis and the first analysis was found to be significant. In terms of GRA\%, between the first and second analyzes, it was observed that the 1st group remained at a value close to the first value with a slight increase, there was a slight increase in the 2nd and 3rd groups, and the highest increase was in the control group. When the final analysis values are examined, it is seen that the 2 nd and 3rd groups are close to each other, and there is a slight decrease in the last analysis compared to the second analysis in the 3rd group. In all other groups there is a gradual increase among all analyzes (Table 4).

\section{Stool Scoring}

From the first week of separation from their mothers and starting to give formula with a bottle, it was observed that there were animals with diarrhea in all three groups every week. While diarrhea $(1=$ watery $)$ was observed only twice in group 1 in the first week, all diarrhea scores increased in the following weeks. Especially in the first group given the formula (in the 3rd week), diarrhea increased by 1, 2, 3 points, and a slight decrease was observed in all three diarrhea points in the following weeks. It is the first group with the highest number of diarrhea points of 1,2, 3 and observations of 21, 19, 16 in a 5-week period. Therefore, the total number of diarrhea observed in different severities in the first group was 56. Group 1 was the highest group in terms of the 


\begin{tabular}{rccccccccc} 
& \multicolumn{8}{c}{ Number of Diarrhea Score Observations } \\
\cline { 2 - 11 } Weeks & \multicolumn{7}{c}{ Group1 } & \multicolumn{7}{c}{ Group2 } & \multicolumn{4}{c}{ Group3 } \\
\cline { 2 - 11 } & Stool & Stool & Stool & Stool & Stool & Stool & Stool & Stool & Stool \\
& Score & Score & Score & Score & Score & Score & Score & Score & Score \\
& 1 & 2 & 3 & 1 & 2 & 3 & 1 & 2 & 3 \\
\hline 1 & 2 & & & 2 & 2 & 3 & 5 & 2 & 3 \\
2 & 2 & 4 & 2 & 2 & & 3 & 2 & & 2 \\
3 & 9 & 8 & 3 & 3 & 3 & 6 & 1 & 8 & 5 \\
4 & 4 & 6 & 6 & 7 & 3 & 2 & & 4 & 4 \\
5 & 4 & 1 & 5 & 1 & 2 & 2 & 1 & & 1 \\
\hline Total & 21 & 19 & 16 & 15 & 10 & 16 & 9 & 14 & 15 \\
\hline
\end{tabular}

Group 2 and group 3 were the groups using the formula + propolis. In the second week in group 2, no animals with a diarrhea score of 2 were seen and the number of diarrhea was observed to decrease. In Group 2, according to $1,2,3$ diarrhea scores, 15, 10, 16 diarrhea, and 41 diarrhea in total were observed, respectively. In the third group of kids, 1, 2, 3 diarrhea points and total diarrhea frequency during 5 weeks are 9, 14, 15 and 38, respectively. In the control group, 1 point diarrhea was observed 2 times only in the 4 th week due to the maternal effect.

\section{DİSCUSSION}

During our study, the average temperature humidity index was determined between $10.58 \%$ and $16.72 \%$. According to the THI values found in our study that it was thought that there was no heat stress on animals (Marai et al. 2007).

It is an important result of the study that there was no statistically significant difference between the body weight gains of the control group during the study and the weight gains of the other three groups fed with the formula. During the experiment, the kids started to be given $400 \mathrm{cc}$ of food per day, it was increased to a maximum of $1100 \mathrm{cc}$ per day and gradually decreased when the kids started to eat concentrate.

In a study conducted by Gubicza and Molnar (1987) on calves, it was determined that 2 cc propolis supplementation caused a significant increase in live weight of calves. Supplementation of propolis during the growth period has been reported to cause an increase in calf live weight (Gubicza and Molnar 1987) and lamb live weight after weaning (Ittavo et al. 2011). There is little work on the use of propolis during the nursing period, especially in kids. In a study conducted on Nubian goats in Egypt, they reported that $0.6 \mathrm{ml}$ of propolis supplementation positively affected the body weight gain and that propolis supplement could be added to milk instead of colostrum (Sadek et al. 2020). In this study; The difference between the average live weight of kids in all groups was found to be insignificant. In some studies, it has been reported that propolis is more effective with rumen development in terms of live weight gain (Morsy et al. 2011). Detection of VKP allows practical understanding of changes and sudden decreases and increases in condition that are difficult to distinguish from the outside in animals (Cobb 2005). In our study, the highest VKP value at the end of the trial was determined in the group fed with 1.84 and $0.4 \mathrm{cc}$ propolis + formula. 
There was no significant difference between groups in terms of body measurements. However, the groups given propolis were found to be higher than the groups that only consumed formula.

At the end of the study, the highest body length with $46.7 \mathrm{~cm}$ belongs to the control group. In the second row, there was the 3rd group, which was fed with $46.1 \mathrm{~cm}$ of food $+0.2 \mathrm{cc}$ of propolis, and the third row was the second group, which consumes $0.4 \mathrm{cc}$ of propolis + food. In the last row, there was the first group that was grown only with formula. At the end of the trial, the highest average measure of wither was $43.9 \mathrm{~cm}$ and $0.4 \mathrm{cc}$ propolis + formula was given in the group.

At the end of the trial, average body temperatures were $39.53{ }^{\circ} \mathrm{C}$ in the control group, $39.45^{\circ} \mathrm{C}$ in the group given $0.4 \mathrm{cc}$ propolis + formula, $39.30^{\circ} \mathrm{C}$ in the group given $0.2 \mathrm{cc}$ propolis + formula, and $39.24{ }^{\circ} \mathrm{C}$ in the group given only formula. All measurement values are also close to literature values (Helal et al. 2010). When we evaluate the body temperature of Capricorns; On the 14th day, the difference between the 1st group given only formula and the 2nd and 3rd groups with propolis supplement was found to be significant ( $p<0.05$ ). On the 37th day, the difference between group 2 and group 1 and 3 was statistically significant $(\mathrm{p}<0.05)$. Changes in body temperature are an important indicator of the animals' ability to adapt to the environment, their health status and their defense mechanisms against infections. In addition, body temperature of goats changes according to the seasons (Minka and Ayo, 2016).

A significant difference was found between the group averages in terms of glucose values measured on the 15th day of the experiment. The highest glucose value was $142.5 \mathrm{mg} / \mathrm{dL}$ in the third group fed with $0.2 \mathrm{cc}$ propolis + the formula. It is followed by the second group fed with $111.8 \mathrm{mg} / \mathrm{dL}$ and $0.4 \mathrm{cc}$ propolis + formula, respectively.

It is an important result of the study that the glucose levels of the groups fed with food and different doses of propolis were higher than the control group and the first group fed only the formula. Again, in the last analysis, the third group fed with $0.2 \mathrm{cc}$ propolis + the formula was the group with the highest glucose level. Elitok et al. (2012) found the glucose value of $42.34 \mathrm{mg} / \mathrm{dL}$ in 1 month old saanen goats in their study. In this study, glucose values in all groups were much higher than this value and almost twice.

Although the normal value of urea in blood in goats ranges between 4-80 mg / dL, the average value was given as $25 \mathrm{mg} / \mathrm{dL}$ (Mbassa and Poulsen 1991). All urea values in our study were found in this value range. In the first two analyzes, no difference was observed between the groups, and in the final analysis, the urea values of the formula-fed groups were found to be significantly different from the control group. When the control group was evaluated within itself, there was no difference between the first two analyzes, but a significant difference was found between the first two analyzes and the last analysis ( $p<0.05$ ). Elitok et al (2012) found the average urea value of $18.31 \mathrm{mg} / \mathrm{dL}$ in 1-month-old Saanen kids. All groups in our study are close to these values and within the specified reference range.

The altitude of the region where the animals are located can affect some hematological values in kids. RBC and HGB ratios of Saanen goats raised in the high altitude region were found to be higher than the RBC and HGB ratios in all groups in this study (Elitok 2012).In a study conducted in Egypt, it was observed that the HGB rates 
in kids who were given propolis twice a week in different doses and nanopathic form during the sucking period, varied between 13 and 23 (g/dL) (Sadek et al. 2020). In this study, it was seen that the group with the most stable HGB rates for all three analyzes was the kids in the second group.

In this study, the difference between\% hct rates between weeks was found to be significant only in the control group. It was determined that the progressive analysis values were lower (24.6\%) compared to the first analysis hct $(26.2 \%)$ in the control group. This decrease was thought to be due to the kids consuming too much milk. At the end of the trial, the highest hematocrit level $(25.1 \%)$ was found in the second and third groups who were supplemented with propolis.

The hematocrit value was found as $29.4 \%$ in West African Dwarf Goats (Daramola et al. 2005), 33.83\% in Saanen goats and $23.40 \%$ in hair goats Türkyılmaz (2003).With this study, it was seen that feeding kids with PAST-containing food in the early period will not cause an anemic problem. In addition, it is an important result that the highest HTC rate was in the groups given propolis in the last analysis.

In this study, the MCH values obtained for all groups were found to be quite high compared to studies conducted in different races and different regions. (Zumbo et al. 2011; Elitok 2012 ; Habibu et al. 2017).

When evaluated in general, it was important that there was a gradual decrease in LYM\% rates in all groups in this study. The decreases in group 2 given propolis and control groups were found to be statistically significant. The initial analysis LYM\% values for group2 and control groups were 54.4 and 43.5, respectively. In the last analysis, these values decreased to 44.9 and 38.2, respectively (Table 4). In another study in which propolis was given in different doses and nanoparticles twice a week, it was reported that the LYM\% rates of goat's kids varied between 34 and 40 in the suction period. In the same study, LYM\% was found to be 37 in the control group (Sadek et al., 2020). In Red Sokoto and Sahel kids, the highest and lowest LYM\% values were found as 54.36-59.54 and 59.17- 65.98, respectively, in different seasonal conditions (Habibu et al. 2017).

The first analysis monocyte mean $(3.79 \%$ and $3.60 \%)$ of the first group and control groups increased in the final analysis values $(6 \%$ and $8.32 \%)$. These are the two groups with the highest increase among the groups. The initial and final analysis monocyte mean values of the kids in the second group given 0.4 cc propolis are very close $(4.22 \%-4.79 \%)$.Monocyte ratios were found to vary between $4.66 \%$ and $5.66 \%$ for kids who were given propolis in different doses and nanoparticular form twice a week. In the same study, the monocyte value was found to be $5.0 \%$ in the control group (Sadek et al. 2020).

It has been reported in some studies that propolis increases feed utilization and has a positive effect on rumen metabolism (Öztürk et al. 2010; Morsy et al. 2011; Morsy et al. 2015). In this study, this was the period when goats could easily eat on feed when they were 35-40 days old. In this period, GRA values of the 2 nd and 3 rd groups given propolis were found to be lower than the other two groups (control and 1st group given only formula). In a study, it was demonstrated that different doses of propolis supplementation improved the productivity, oxidative status and immune response of Barki sheep and lambs in Egypt (Shedeed et al. 2019).

In another study, the stool score of the calf group given propolis was found to be 3 , which is the most suitable and optimum score (Tolon et al. 2002). In a study in which propolis was added to the ration of piglets, it was 
found that diarrhea was 52\% lower in the propolis group than the control group fed the same ration (Guo \& Ding, 2010). In this study, the least diarrhea score was seen in group 3 in all three groups given the formula. It was observed that morning diarrhea ceased in the evening and evening diarrhea stopped in the morning in both groups given propolis. Diarrhea was not observed for a long time in the same animal. As a result of the study, it was that propolis was effective on diarrhea. It has been observed that propolis could be used to grow kids as a preventive measure against diarrhea.

382

In terms of economics, the cost of one animal in the control group was 7.30 TL per day, and 1.81 TL for the experimental groups. In addition, since the mothers of the kids were milked, an additional income has been provided to the business. It is known that milk yield of dairy goats peaked in the first 2 months. It is not economical to use milk in kid feeding during this period. It was determined by this study that it is much more economical to separate the kids from their mothers in the first week after taking colostrum and to feed them with a mixture containing cow's milk and Whey, In many studies on ruminants, propolis was added to food in powder form without being extracted, and positive results were obtained (Lana et al., 2007). Considering the raw price of propolis, it is not economical to use it in this way. In our study, ethanolic extract of propolis was used. The daily cost per animal was found to be $0.4 \mathrm{TL}$.

\section{Result}

According to the results of body measurements, body temperatures, stool scoring and blood analysis of the kids in the study, it was observed that Saanen kids grown with propolis supplement and PAST food showed the same development as the kids fed with mother milk. It was concluded that it would be economical in all respects to use whey and whey powder, which is seen as waste, especially for goat rearing during and after the suction period.

Propolis and its level were effective on body temperature in kids. The Formule and different doses of Propolis had a positive effect especially on the glucose value of the boys during the nursing period. It was concluded that goats consuming propolis benefit better from energy sources. However, propolis had no effect on blood urea level.

The lower rates of $\mathrm{RBC}, \mathrm{HGB}$ and $\mathrm{HTC}, \mathrm{MCH}$, which are the red blood cells responsible for the transport of oxygen and carbon dioxide in the blood of Saanen goats, could be explained by the fact that Aydin is $52 \mathrm{~m}$ above sea level. The fact that there was no significant difference between the averages of red blood cells between the control group and The formule groups was important in terms of showing that feeding the kids with whey foods did not cause anemic problems. In our study, on the 30th day, it was observed that the highest increase in GRA\% rates was the control group, which was breast milk suckling kids, and the first group, which was given only formula.

The fact that the least diarrhea cases were seen in group 3 and then in group 2 in three groups who were raised without mother, shows that propolis could be used as a diarrhea preventive in growing kids with the formula, but further studies on the subject are recommended. The ethanolic extract of propolis is recommended to be used as a protective and supportive product as a feed additive for kids during suction and rumen development.

\section{Acknowledgement}


The authors would like to thank to Scientific Research Projects Unit of Aydın Adnan Menderes University. This study was compiled from Selda Manav's master's thesis from the Department of Animal Science, the School of Natural and Applied Sciences Aydın Adnan Menderes University.

Author contributions: All authors contributed to the study conception and design. Material preparation and data collection were performed by all authors. Data analysis was performed by all authors. All authors read and approved the final manuscript.

Funding: Within the scope of project numbered ZRF-20015 from Scientific Research Projects Unit of Aydın Adnan Menderes University financial support was received for this study.

\section{DECLARATIONS}

Compliance with ethical standards: The authors declare that the manuscript complies with the Ethical Rules applicable for Tropical Animal Health and Production journal.

Conflict of interest: The authors declare that they have no conflict of interest.

Consent to participate: Verbal informed consent was obtained from respondents prior to the interview.

Data availability statement:The datasets generated during and/or analysed during the current study are available from the corresponding author on reasonable request.

\section{REFERENCES}

Abdolvahabi, S., Zaeemi, M., Mohri, M., Naserian, A. A. 2018. The hematological profile changes in Saanen goat kids from birth to 3 months of age. Iranian Journal of Veterinary Science and Technology, 10(1): 33-38.

AL-Khafaji, M.W.S. 2016. Effect of Iraqi Propolis on Live Body Weight of Awassi Sheep in Different Age Stages. Kufa Journal for Agricultural Sciences, 8 (1), 261-269.

Aygun, A., Sert, D. 2013. Effects of prestorage application of propolis and storage time on eggshell microbial activity, hatchability, and chick performance in Japanese quail (Coturnix coturnix japonica) eggs. Poult Sci., 9212:3330-7.

Ayışığı, K., Ataşoğlu, C., Yurtman, İ.Y., Mendeş, M., Pala, A. 2005. Effect of Probiotic Supplementation Shortly Before and After Weaning on Growth of Turkish Saanen Kids. Arch, Tierz, Dummerstorf 48 (6), 601 611

Aytuğ, C.N., Alaçam, E., Görgül, S., Gökçen, H., Tuncer, Ş.D., Yılmaz, K. 1991. Sığır Hastalıkları, 2. Baskı, Tümvet Ltd. Şti., Teknografik Matbaası, İstanbul.

Bonamigo, T., Campos, J. F., Oliveira, A.S., Torquato, H.F.V., Balestieri, J.B.P., Cardoso, C.A.L., ParedesGamero, E.J., de Picoli Souza, K., Dos Santos, E.L. 2017. Antioxidant and Cytotoxic Activity of Propolis of Plebeia Droryana and Apis Mellifera (Hymenoptera, Apidae) from the Brazilian, Plos one 12(9). https://doi.org/10.1371/journal. pone.0183983 

189.

Chudoba-Drozdowska, B., Kupczyński, R., Roman, A. 2003. Application of Humowitan Preparation or Propolis Extract to Calves With Diarrhoea Symptoms, Acta Scientiarum Polonorum-Medicina Veterinaria, 2 (2): $73-83$. parameters of west African Dwarf goats. Livestock Research for Rular Development, 17 (8):95.

Denli, M., Cankaya, S., Silici, S., Okan, F., Uluocak, A.N., 2005. Effect of Dietary Addition of Turkish Propolis on the Growth Performance, Carcass Characteristics and Serum Variables of Quail (Coturnix coturnix japonica). Asian-Australasian Journal of Animal Sciences, 18(6): 848-854.

Elitok, B. 2012. Reference values for hematological and biochemical parameters in Saanen goats breeding in Afyonkarahisar province. Kocatepe Veteriner Dergisi, 5(1):7-11.

Freitas, J. A., Vanat, N., Pinheiro, J. W., Balarin, M. R. S., Sforcin, J. M., Venancio, E. J. 2011. The Effects of Propolis on Antibody Production by Laying Hens. Poultry Science, 90(6): 227-1233.

Galina, M. A., Palma, J. M., Pacheco, D., Morales, R. 1995. Effect of goat milk, cow milk, cow milk replacer and partial substitution of the replacer mixture with whey on artificial feeding of female kids. Small Ruminant Research, 17(2): 153-158.

Gubicza, A., Molnar, P. 1987. Propolis in the rearing of calves 254. Magyar Mezogazdasag, 42(17): 14.

Guo, D. S., Ding, S. L. 2010. Effect of basal diet supplemented with propolis on production performance of weaned piglets. Animal Husbandry and Feed Science, 9: 18-19.

Habibu, B., Kawu, M., Makun, H., Aluwong, T., Yaqub, L., Dzenda, T., Buhari, H. 2017. Influences of breed, sex and age on seasonal changes in haematological variables of tropical goat kids. Arch. Anim. Breed., 60, 3342.

Habibu, B., Kawu, M., Makun, H., Aluwong, T., Yaqub, L., Dzenda, T., \& Buhari, H. (2017). Influences of breed, sex and age on seasonal changes in haematological variables of tropical goat kids. Archiv fuer Tierzucht, 60(1): 33 .

Harish, Z., Rubinstein, A., Golodner, M., Elmailah, M., Mizrachi, Y. 1997. Suppression of HIV-I Replication by Propolis and its Immunoregulatory Effect. Drugs Exp Clin Res., 23: 89-96.

Hašèík, P., Elimam, I., Garlík, J., Kacániová, M., Cuboò, J., Bobko, M., Abdulla, H. 2012. Impact of Bee Pollen as Feed Supplements on the Body Weight of Broiler Ross 308. African Journal of Biotechnology, 11: 1559615599. 
Helal, A., Youssef, K. M., El-Shaer, H. M., Gipson, T. A., Goetsch, A. L., Askar, A. R. 2010. Effects of acclimatization on energy expenditure by different goat genotypes. Livestock Science, 127(1): 67-75.

Holmøy, I.H., Waage, S. 2015. Time Trends and Epidemiological Patterns of Perinatal Lamb Mortality in Norway. Acta Veterinaria Scandinavica, 57: 65-76.

Ítavo, C. C. B. F., Morais, M. G., Costa, C., Ítavo, L. C. V., Franco, G. L., Da Silva, J. A., Reis, F. A. 2011. Addition of propolis or monensin in the diet: Behavior and productivity of lambs in feedlot. Animal Feed Science and Technology, 165(3-4): 161-166.

Kara, K., Güçlü, B. K., Oğuz, F. K. 2014. Use of Propolis and Phenolic Acids in Ruminant Nutrition. Erciyes Üniversitesi Veteriner Fakültesi Dergisi. 11(1): 43-53 ref.74.

Karslı, M.A., Evci, Ş. 2018. Buzağı Kayıplarının Önlenmesinde İnek ve Buzağı Beslemesinin Önemi. Lalahan Hay. Araşt. Enst. Dergi, 2018, 58 (Özel Sayı): 23-34.

Katircioğlu, H., Mercan, N. 2006. Antimicrobial Activity and Chemical Compositions of Turkish Propolis from Different Region. African Journal of Biotechnology, 5 (11): 1151-1153.

Kocot, J., Kiełczykowska, M., Luchowska-Kocot, D., Kurzepa, j., Musik, I. 2018. Antioxidant Potential of Propolis, Bee Pollen, and Royal Jelly: Possible Medical Application. Oxidative Medicine and Cellular Longevity, https://doi.org/10.1155/2018/7074209

Kujumgiev, A., Tsvetkova, I., Serkedjieva, Yu., Bankova, V., Christov, R., Popov, S. 1999. Antibacterial, antifungal and antiviral activity of propolis of different geographic origin. J Ethnopharmacol., 64: 235-240.

Kupczyński, R., Adamski, M., Falta, D., Roman, A. 2012. The efficiency of propolis in post-colostral dairy calves. Arch Tierz, 55: 315-324.

Littell, R. C., Milliken, G. A., Stroup, W. W., Wolfinger, R. D. 1997. SAS system for mixed models. SAS Institute Inc Cary NC.

Marai, I.F.M., Abou-Fandoud, E.I., Daader, A.H., AbuElla, A.A., 2002. Reproductive doe traits of the Nubian (Zaraibi) goats in Egypt. Small Rumin. Res., 46: 201-205.

Marai, I.F.M., El-Darawany, A.A., Fadiel, A., Abdel-Hafez, M.A.M. 2007. Physiological traits as affected by heat stress-a review. Small Ruminant Research, 71: 1-12.

Mbassa, G.K., Poulsen, J.S. 1991. Influence of pregnancy, lactation and environment on some clinical chemical reference values in Danish landrace dairy goats (Capra hircus) of different parity-II. Plasma urea, creatinine, bilirubin, cholesterol, glucose and total serum proteins. Comparative Biochemistry Physiology Part B, Comparative Biochemistry 100: 423-431.

Minka, N S and Ayo, J O 2016 Effects of Cold-Dry (Harmattan) and Hot-Dry Seasons on Daily Rhythms of Rectal and Body Surface Temperatures in Sheep and Goats in a Natural Tropical Environment. Journal of Circadian Rhythms, 14(1): 8, pp. 1-11, DOI: http://dx.doi.org/10.5334/jcr.143 

Effect of two types of Brazilian propolis extracts on rumen gas and methane production and truly degradability in vitro. Middle East. North African Journal of Animal Science, 4: 446-456.

513

Morsy, A. S., Soltan, Y. A., Sallam, S. M. A., Kreuzer, M., Alencar, S. M., Abdalla, A. L. 2015. Comparison of the in vitro efficiency of supplementary bee propolis extracts of different origin in enhancing the ruminal degradability of organic matter and mitigating the formation of methane. Animal Feed Science and Technology, 199: 51-60.

Murad, J.M., Calvi, S.A., Soares, A.M.V.C., Bankova, V., Sforcin, J.M. 2002. Effect of propolis from Brazil and Bulgaria on Fungucidal Activity of Macrophages Against Paracoccidioides Brasiliensis. J. Ethnopharmacol., 79: 331-334.

Onur, E., Nalbantsoy, A., Kışla, D. 2018. İmmünoterapi ve Propolisin Kanser İmmünoterapisinde Kullanım Potansiyeli. Food and Health, 4(4): 231-246 • DOI: 10.3153/FH18023.

Öztürk, H., Pekcan, M., Sireli, M., Fidanç, U.R. 2010. "Effects of Propolis on in Vitro Rumen Microbial Fermentation. Ankara Üniversitesi Veteriner Fakültesi Dergisi, 57 (4): 217-221.

Pinheiro, J., Douglas, B., Saikat D. R., Deepayan S. and the R Development Core Team (2013). nlme: Linear and Nonlinear Mixed Effects Models. R package version 3.1-108.

Russell, A. J. F., Doney, J. M., Gunn, R. G. 1969. Subjective Assessment of Body Fat in Live Sheep. J. Agric. Sci., 72: 451-454.

Sadek, W. M. A., El-Houssiny, A. S., Al-Mwafy, A., Farag, T. K., Al-Gethami, A., Grawish, S. I. M., Hegazi, A. G. 2020. Egyptian propolis 16: The effect of consumption of propolis and alginate-propolis nanoparticles in combination with colostrum on the performance of newborn goats. Adv. Anim. Vet. Sci, 8(12): 1256-1265.

Seven, İ., Aksu, T., Seven, P.T. 2007. Propolis ve Hayvan Beslemede Kullanımı. Yüzüncü Yıl Üniversitesi Veteriner Fakültesi Dergisi, 18(2): 79-84.

Shedeed, H.A., Farrag, B., Elwakeel, E.A., Abd El-Hamid, I.S., El-Rayes, M.A. 2019. Propolis supplementation improved productivity, oxidative status, and immune response of Barki ewes and lambs. Veterinary World, 12(6): 834-843.

Silici, S. 2015. Propolis üzerine ön klinik araştırmalar. Erciyes Üniversitesi Fen Bilimleri Dergisi, 31(3): 185191.

Tekeli, A., Kutlu, H.R., Celik, L. 2011. Effects of Z. Officinale and Propolis Extracts on the Performance, Carcass and Some Blood Parameters of Broiler Chicks. Current Research in Poultry Science. 1 (1): 12-23.

Tolon, B., Önenç, A., Kaya, A., Altan, Ö. 2002. Effects of propolis on growth of calves.1st German Congress for Bee Products and Apitherapy. 23-24 March, Passau-Germany.P.71. 
542 Türkyılmaz, B. 2003. Sannen Irkı Keçiler ve Kıl Keçilerinde Eritrosit İçi Potasyum ve Glutatyon Tiplerinin 543 Karşılaştırılması. Uludağ Üniversitesi Sağlık Bilimleri Enstitüsü Yüksek Lisans Tezi, (Basılmamış), Bursa.

544 Ünal, H. B., Taşkın, T., Kandemir, Ç. 2018. Küçükbaş Hayvancılıkta Yavru Ölümlerinin Azaltılmasına Yönelik

545 Barındırma ve Yetiştirme Uygulamaları. J. Anim. Prod., 59 (2): 55-63.

546 Ünlü, H.B., Erkek, R., Özdoğan, M., Mert, S. 2013. "Buzağı Beslemede Doğal Yem Katkı Maddelerinin

547 Kullanımı", Hayvansal Üretim 54(2), 36-42.

548 Velikova, M., Bankova, V., Sorkun, K., Houcine, S., Tsvetkova, I., Kujumgiev, A. 2000. Propolis from the

549 Mediterranean region: chemical composition and antimicrobial activity. Z Naturforsch [C]., 55(9-10): 790-793.

550 Yang, M. S. J. 2010. Propolis and İllite as Feed Additives on Performance and Blood Profiles of Pre-Weaning 551 Hanwoo Calves. Journal of Animal and Veterinary Advances, 9(19): 2526-2531.

552 Zeedan, K. I. I., Komonna, O. F. 2013. Improvement of immunological and productive performance for 553 buffaloes by using some natural additive. 1-Effect of propolis as feed additive on productive and reproductive 554 performance. Egyptian Journal of Nutrition and Feeds, $16(2$ (Special Issue)): 35-54.

555 Zeng, Z., Zhang, S., Wang, H., Piao, X. 2015. Essential Oil and Aromatic Plants as Feed Additives in Non556 Ruminant Nutrition: a Review. Journal of Animal Science and Biotechnology, 6(7): 2-10.

557 Zumbo, A., Sciano, S., Messina, V., Casella, S., di Rosa, A. R., Piccione, G. 2011. Haematological profile of 558 messinese goat kids and their dams during the first month post-partum. Animal Science Papers \& Reports, $55929(3): 223-230$. 